\title{
Nitrogen and Phosphorus Uptake Efficiency and Partitioning of Container-grown Azalea During Spring Growth
}

\author{
Andrew G. Ristvey ${ }^{1}$ \\ Maryland Cooperative Extension, Wye Research and Education Center, P.O. Box 169, \\ Queenstown, MD 21658
}

\author{
John D. Lea-Cox \\ Department of Plant Science and Landscape Architecture, University of Maryland, \\ College Park, MD 20742 \\ David S. Ross \\ Department of Environmental Science and Technology, University of Maryland, \\ College Park, MD 20742
}

\begin{abstract}
AdDitional INDEX words. leaching, greenhouse, nutrients, loading, Rhododendron
Abstract. The influence of fertilization rate on nitrogen $(N)$ and phosphorus $(P)$ nutrient partitioning and uptake efficiency of young, container-grown azalea (Rhododendron $\mathrm{L}$. 'Karen') was determined under controlled greenhouse conditions during Spring 2001 and 2002. In 2001, fertilizer treatments included a factorial combination of two $N(25$ or $250 \mathrm{mg} /$ week) and three $P(0,5$, or $25 \mathrm{mg} /$ week) rates; in 2002, an additional $\mathrm{N}$ rate $(100 \mathrm{mg} /$ week) was included in the experimental design. Five destructive harvests were performed during each study; plant tissues (root, stem, primary and secondary branches and leaves) from each harvest were analyzed to derive total $\mathrm{N}$ and $\mathrm{P}$ uptake. Leachates from containers were monitored and analyzed weekly to calculate nitrate $\left(\mathrm{NO}_{3}-\mathrm{N}\right)$, ammonium $\left(\mathrm{NH}_{4}-\mathrm{N}\right)$, and orthophosphate $\left(\mathrm{PO}_{4}-\mathrm{P}\right)$ loss. Fertilization rates of $5 \mathrm{mg} \mathrm{P}$ per week in 2001 and rates of $100 \mathrm{mg} \mathrm{N}$ per week and $5 \mathrm{mg} P$ per week in 2002 maintained optimal growth compared with the highest fertilization rates $(250 \mathrm{mg} N$ and $25 \mathrm{mg} P$ per week) in these studies. Increasing $N$ fertilization rate largely promoted shoot growth, whereas decreasing $N$ and $P$ fertilization rates promoted root growth and increased uptake efficiency. In general, increasing $N$ and $P$ fertilization rates increased nutrient $N$ and $P$ leaching from the pine bark substrate. Reducing excess $N$ and $P$ fertilization to match plant growth requirements of young azalea increases nutrient uptake efficiency and reduces nutrient loss to the environment.
\end{abstract}

Some quantitative physiological data on nitrogen $(\mathrm{N})$ and phosphorus (P) uptake by woody ornamental species are available in the literature (Cabrera, 2003; Cabrera and Devereaux, 1998; Craig et al., 2003; Griffin et al., 1999), but few ornamental studies have provided total nutrient budgets for plant uptake and loss. Also, few studies have related N and P availability (from fertilization) to nutrient uptake and nutrient uptake efficiency by ornamental species. Little is also known about how woody ornamentals grown in intensive plant production systems partition $\mathrm{N}$ and $\mathrm{P}$ in part because of the periodicity of their growth cycles and the fact that nutrient uptake is greatly influenced by other environmental variables such as water availability and temperature (Marschner, 1995).

Among the nutrient elements required for plant growth, $\mathrm{P}$ is associated with growth of meristematic tissue and in particular root growth (Tisdale et al., 1985; Wittwer, 1969). There is widespread belief in the ornamental industry that $P$ fertilization stimulates root growth over shoot growth. In a review of root:shoot ratios in trees, Harris (1992) cited seven examples

Received for publication 1 May 2006. Accepted for publication 5 Apr. 2007. We gratefully acknowledge funding from the Maryland Department of Environment, the University of Maryland Agricultural Experiment Station, the Maryland Nursery and Landscape Association and The Conard Pyle Company, who supported this research.

${ }^{1}$ Corresponding author. E-mail: aristvey@umd.edu. of books or manuals on plant care that either stated or implied that increasing $\mathrm{P}$ rates promoted root growth and increasing $\mathrm{N}$ fertilization promotes shoot growth. The belief that P fertilization preferentially stimulates root growth over shoot growth persists and is evident in conventional horticultural systems in which fertilizers with low N:P ratios are still used (Hansen and Lynch, 1998; Williams and Nelson, 1996). However, there are few definitive experimental data in the literature to support this contention. There are some data to show that P-starved roots grow and branch more profusely when $\mathrm{P}$ is added to their environment (Drew and Saker, 1978), but there is no evidence to indicate that the addition of higher levels of $\mathrm{P}$ increases either root or shoot growth rates above that of minimally P-sufficient plants. Indeed, Anghinoni and Barber (1980) showed that minimal substrate P concentrations increased root-to-shoot dry weight ratios in corn (Zea mays L.). Dufault (1985) also found that root-to-shoot ratios decreased with increasing $\mathrm{P}$ fertilization levels in celery (Apium graveolens L.) transplants. Evidence shows that low P fertilization improves root growth over high $\mathrm{P}$ rates in herbaceous species such as impatiens (Impatiens wallerana Hook. F. 'Impulse Orange') and marigold (Tagetes patula L. 'Janie Tangerine') (Borch et al., 1998), chrysanthemum (Dendranthema $\times$ grandiflorum Ramat. 'Coral Charm') (Hansen and Lynch, 1998), common bean (Phaseolis vulgaris L.) (Lynch et al., 1991) and in some woody species (Zhang et al., 2002). Other studies have shown that P did not 
promote root growth or influence root-to-shoot ratio in a wide range of plants (Broschat and Klock-Moore, 2000; Dufault and Schultheis, 1994; Melton and Dufault, 1991; Weston and Zandstra, 1989; Yeager and Wright, 1982).

We hypothesize that current $\mathrm{N}$ and $\mathrm{P}$ application rates to many ornamental species in container production exceed normal plant $\mathrm{N}$ and $\mathrm{P}$ growth requirements resulting in low uptake efficiencies and excessive nutrient loss through leaching. A review by Chen et al. (2001) noted that recommended $\mathrm{N}$ rates for greenhouse-grown azalea were $2200 \mathrm{~kg} \cdot \mathrm{ha}^{-1}$ per year, over 10 times the agronomic rate for corn. This equates to applying $500 \mathrm{mg} \mathrm{N}$ per week to a plant in a 7.6-L container over a 40 -week growing cycle (given $110,000 \times 7.6$-L containers per hectare). Borch et al. (1998) noted that levels of $\mathrm{P}$ fertilization are orders of magnitude greater than plant requirements; plants grow well at $\mathrm{P}$ concentrations 100 -fold less than traditional rates used in container plant production (Lin et al., 1996; Lynch et al., 1991) as long as available $\mathrm{P}$ concentrations are held constant in the soil solution.

Specifically, we hypothesize that rates of $100 \mathrm{mg} \mathrm{N}$ and $5 \mathrm{mg}$ $P$ per plant each week will 1) maintain maximal shoot and root growth rates of young (less than 2 years old) azalea plants, and 2) increase $N$ and $P$ uptake efficiency and reduce $N$ and $P$ leaching (loss) from containers. Azalea was chosen as a model ericaceous ("low nutrient use") woody perennial, because it is widely grown in the nursery and landscape industry throughout the United States. There are few data on nutrient uptake and use efficiency for container-grown azalea. A few studies on other species such as poinsettia (Euphorbia pulcherrima Wild.) (Ku and Hershey, 1992; Rose et al., 1994) or in woody ornamentals (Tyler et al., 1996) have examined nutrient use from the perspective of reducing nutrient concentrations in fertilizer applications, aiming to reduce leaching without impacting plant growth or quality. Research by Sandrock et al. (2005) investigated $\mathrm{N}$ nutrition of Weigela florida Bunge 'Red Prince' and Euonymus alatus Thumb. 'Compactus' based on periodicity of growth and nutrient requirements. Other researchers have studied nutrient uptake and seasonal partitioning physiology of Rhododendron ferrugineum L. in natural ecosystems, contributing much to the knowledge base (Lamaze et al., 2003; Pasche et al., 2002). The objectives of this study were to investigate growth and nutrient uptake of 12- to 18-month-old azalea plants under different combinations of $\mathrm{N}$ and $\mathrm{P}$ fertility, develop $\mathrm{N}$ and $\mathrm{P}$ budgets, and recommend fertility rates that optimize growth and nutrient uptake efficiency, yet minimize nutrient leachate potential.

\section{Materials and Methods}

SPRING STUDY 2001. An initial experiment was conducted over a 10-week period from March to May 2001 to investigate the uptake and partitioning of $\mathrm{N}$ and $\mathrm{P}$ by 'Karen' azalea. Five replicates of six treatments in a completely randomized $2 \times 3$ factorial design provided (growth) limiting and non-limiting rates of $\mathrm{N}$ (i.e., 25 and $250 \mathrm{mg} /$ week, respectively) and limiting, sufficient, and high rates of $\mathrm{P}(0,5$, and $25 \mathrm{mg} / \mathrm{week}$, respectively) to azalea plants. These rates were extrapolated from previous studies on azalea (Ristvey, 2004) and other information from the literature (Chen et al., 2001).

Twelve-month-old azalea liner plants were purchased in Aug. 2000 from a wholesaler for the 2001 experiment. Liner azaleas were given a $20 \mathrm{~N}-4.4 \mathrm{P}-16.6 \mathrm{~K}$ completely soluble fertilizer (Peters Professional General Purpose Water Soluble Fertilizer; Scotts Co., Marysville, $\mathrm{OH}$ ) at $200 \mathrm{mg} \cdot \mathrm{L}^{-1} \mathrm{~N}$ once per week for 6 weeks. Fertilization was discontinued and azalea liners were not fertilized for 8 weeks before onset of this study to reduce the nutrient reserves of the plants and substrate. Daily watering during this period assured a fully leached substrate. Within the greenhouse, seasonal natural ambient light was provided. Temperatures were controlled within a diurnal range of 20 to $28{ }^{\circ} \mathrm{C}$ during the experimental period. Liner plants exhibited a limited dormancy (no shoot growth) during part of December and January, although no dormant buds were formed. A few plants exhibited limited flowering during the study with no more than three blooms on a plant. Those flowers were collected as leaf samples during harvests. Azalea liners were transplanted into 7.6-L Classic \#2 plastic pots (Nursery Supplies, Chambersburg, PA) filled with a composted pine bark media consisting of equal parts composted pine bark, sphagnum peat, and rice hulls and amended with iron sulfate $\left(0.22 \mathrm{~kg} \cdot \mathrm{m}^{-3}\right)$ and Micromax (The Scotts Co.) micronutrients $\left(0.68 \mathrm{~kg} \cdot \mathrm{m}^{-3}\right)$.

Plants received an initial nutrient application and 10 weekly applications (total of 11 applications) of $\mathrm{N}$ and $\mathrm{P}$ in an otherwise balanced liquid fertilizer solution (Ristvey, 2004) at the rates specified previously for each treatment throughout the 10-week experimental period. The fertilizer was applied to each plant in $250-\mathrm{mL}$ aliquots once per week. Between fertilizations, all plants were deficit irrigated twice per week (i.e., with a zero leaching fraction by using a balance and records of the initial weight at container capacity); in addition, all plants were watered to excess on the day before each fertilization event and the resulting leachate volume recorded with an aliquot preserved and frozen for nutrient analysis. This irrigation was designed to leach the excess $\mathrm{N}$ and $\mathrm{P}$ and any other accumulating salts remaining in the substrate from the previous week. The first destructive plant harvest was performed before the onset of the study to provide baseline dry weight and nutrient content data. Five further plant harvests were conducted every 2 weeks to provide sequential plant $\mathrm{N}$ and $\mathrm{P}$ uptake, partitioning, and use efficiency data.

Plant tissue analysis. During each harvest, the plants were divided into roots, stems, primary and secondary branches, and leaf tissue. Root tissue was separated from stem tissue and cleaned of all substrate by physical shaking and washing with three successive quick rinses of water. Care was taken in recovering all root tissue by draining all wash water, between rinses, through a \#30 $(600 \mu \mathrm{m})$ sieve. Stem tissue comprised the main trunk of the plant. Primary branches included all woody tissue branching directly from the stem. Secondary branch tissue was denoted as all branches other than primary branch tissue. Tissues were separated at each harvest and fresh weights taken. A 10- to 15-g subsample of each tissue from each replicate plant was freeze-dried using a lyophilizer (Labconco, Kansas City, KS). Any additional tissue was dried in a forcedair ventilated oven at $40{ }^{\circ} \mathrm{C}$ for 72 to $96 \mathrm{~h}$. Dry weights were measured when lyophilization or drying was complete. Each lyophilized subsample was milled through a $1.0-\mathrm{mm}$ screen (Foss/Tecator Mill, model 1093; Foss, Höganäs, Sweden) taking care to clean the mill thoroughly between each sample. All tissues were analyzed for total carbon (C) and total $\mathrm{N}$ concentration using a Carlo-Elba Model CE $2000 \mathrm{CN}$ analyzer (CE Elantech, Lakewood, NJ). Precise analytical sample dry weights were noted for each sample to back-calculate total $\mathrm{N}$ and $\mathrm{P}$ contents. Tissues from the initial, third, and final harvests 
of each data set were analyzed for total P using an open vessel microwave system (Star System 6; CEM, Raleigh, NC). Approximately $0.5 \mathrm{~g}$ of each tissue type $(0.2$ to $0.3 \mathrm{~g}$ for leaf tissue) was placed in each microwave vessel containing $0.5 \mathrm{~g}$ of potassium persulfate. Tissues were digested, reconstituted, and analyzed with an Alpkem FS 3000 System NP analyzer (O.I. Analytical, College Station, TX) for total P using the ascorbic acid method (Clesceri et al., 1989). Total $\mathrm{N}$ and $\mathrm{P}$ contents of all tissue samples were back-calculated from all total $\mathrm{N}$ and $\mathrm{P}$ concentration data and from dry weight and sample weight records during this process.

Leachates. Throughout the study, the replicate plants that were designated for the final destructive harvest were placed above catchment saucers to retain leachates. Leachates were collected from these plants once per week, on the same day each week, $1 \mathrm{~h}$ after a hand-delivered irrigation of $1 \mathrm{~L}$. Leachate volumes were recorded and sample aliquots taken. Sample aliquots were taken in replicate $25-\mathrm{mL}$ scintillation vials and preserved with $50 \mu \mathrm{L}$ concentrated sulfuric acid $(32 \mathrm{~N})$. The samples were kept frozen until analyzed for $\mathrm{NO}_{3}-\mathrm{N}, \mathrm{NH}_{4}-\mathrm{N}$, and orthophosphate $\left(\mathrm{PO}_{4}-\mathrm{P}\right)$ concentration using the FS3000 analyzer. Nitrate-N was analyzed using the automated cadmium reduction method, $\mathrm{NH}_{4}-\mathrm{N}$ by the automated phenate method, and total $\mathrm{P}$ and $\mathrm{PO}_{4}-\mathrm{P}$ by the automated ascorbic acid reduction method (Clesceri et al., 1989). Nitrogen and $\mathrm{PO}_{4}-\mathrm{P}$ leachate contents were calculated by multiplying the concentration of each ion by the total volume of the water collected each week.

SubSTRATEs. Residual nutrient contents for each treatment's substrate were quantified at the end of the study. Subsamples from the each replicate within each treatment were combined and one representative sample of $\approx 1 \mathrm{~L}$ in volume was analyzed for each treatment. Substrate analysis was quantified by using the 1:1.5 volume extract method as detailed in Handreck and Black (1994). Each substrate extract was then colorimetrically analyzed using the Alpkem FS 3000 for $\mathrm{NH}_{4}-\mathrm{N}, \mathrm{NO}_{3}-\mathrm{N}$, and $\mathrm{PO}_{4}-\mathrm{P}$ (ortho-P).

INITIAL DATA AND EFFICIENCY CALCULATIONS. In each study, $\mathrm{N}$ and $\mathrm{P}$ plant tissue concentrations were multiplied by tissue dry weight to give tissue nutrient content, which normalized differences in nutrient concentrations as a result of growth differences between treatments. The initial harvest $(n=15$ plants) was performed before the onset of each study to provide baseline dry weight and $\mathrm{N}$ and $\mathrm{P}$ content data. The baseline data were then subtracted from each harvest value for each treatment, giving total dry weight and $\mathrm{N}$ and $\mathrm{P}$ uptake for each treatment every 2 weeks. Because both dry weight and nutrient uptake accumulation values were transformed from dry weight and total nutrient content values using the initial values, both sets of data have the same treatment variances. Uptake data were used to develop the nutrient budgets. The initial harvest at the beginning of the experiment gave a per-plant average of $5.7 \mathrm{~g}$ dry weight, $91.6 \mathrm{mg} \mathrm{N}$ and $20.9 \mathrm{mg} \mathrm{P}$ in the 2001 study, and $7.5 \mathrm{~g}$ dry weight, $104.0 \mathrm{mg} \mathrm{N}$ and $19.0 \mathrm{mg} \mathrm{P}$ in the 2002 study. Plant $\mathrm{N}$ and $\mathrm{P}$ uptake values were then used to calculate uptake efficiencies. Nitrogen and $\mathrm{P}$ uptake efficiency percentages thus only reflect the fraction of applied nutrient accumulated by plants during each 10 -week period.

SPRING STUDY 2002. A repeat experiment, with improvements, was conducted over a similar 10-week period from the end of March through May 2002. Azalea cuttings from mother plants of the original stock were taken in June 2001 and rooted in Oasis Horticubes (Oasis Products, Kent, $\mathrm{OH}$ ) with Hormodin (OHP, Mainland, PA) rooting hormone. After 8 weeks under $4 \mathrm{~s}$ mist every $4 \mathrm{~min}$, rooted cuttings were transferred to $10.2-\mathrm{cm}$ pots containing a 1 peat: 1 vermiculite potting substrate. Preexperimental fertilization of azaleas was similar to previous study, but for 14 weeks. Fertilization discontinued 10 weeks before 2002 study initiation. In this study, nine treatments with three replicates arranged in a completely randomized $3 \times 3$ factorial design provided limiting, sufficient, and high rates of $\mathrm{N}$ (i.e., 25, 100, and $250 \mathrm{mg} \mathrm{N}$ per week, respectively) combined with limiting, sufficient, and high rates of $P(0,5$, and $25 \mathrm{mg} \mathrm{P}$ per week, respectively) to azalea plants. Plants received 18 applications of $\mathrm{N}$ and $\mathrm{P}$ in an otherwise balanced liquid fertilizer solution at the weekly rates specified for each treatment throughout the experimental period. The fertilizer was applied to each plant in $250-\mathrm{mL}$ aliquots twice per week at half rate to minimize any potential salinity effects of the higher rate treatments. Additionally, before the start of the study, an analysis on $\mathrm{N}$ and $\mathrm{P}$ availability was performed on the substrate. All other methods and procedures were the same as for the first study. Several weeks into the study (at harvest 1), plants began showing signs of a leaf-tip necrosis in all treatments. An immediate foliar and substrate analysis revealed a high concentration of manganese $(\mathrm{Mn})$ in both leaves and substrate. It is possible that the Mn originated in the pine bark used in the substrate. Some sources of fresh bark have been documented to have excessive levels of Mn (Solbraa and Selmer-Olsen, 1981). To counteract the effects of Mn accumulation in plant tissues, sodium silicate was added to each fertilizer solution at a $0.05 \mathrm{M}$ concentration. According to Marschner (1995), silicon tends to prevent $\mathrm{Mn}$ accumulation in any one area and promotes the distribution of Mn more evenly throughout plant tissues. The addition of sodium silicate ameliorated the Mn toxicity on all new leaf growth by the third harvest.

Statistical ANALYsis. All sample data were analyzed using a factorial analysis of variance using the PROC MIXED routine (SAS Institute, Cary, NC). If treatment interaction was not significant, main effects are reported and discussed. However, if treatment interactions were significant, simple effects (the effect of a variable at a specific level of another variable) are reported and discussed. Pairwise comparisons were done under least significant differences (LSD) criteria at $P \leq 0.05$ to increase the power of the test and protect the analysis interpretation from incorrectly accepting the null hypothesis (type II error). The use of LSD increases the power of the test and hence, increases the probability of detecting a real effect.

\section{Results}

DRY WEIGHT. Both studies show that high nutrient application rates do not significantly increase total plant dry weight or shoot dry weight over the moderate $\mathrm{N}$ and $\mathrm{P}$ rates in this study. Azalea total dry weight results from each final harvest are summarized and compared in Table 1 . There was no difference in total dry weight or shoot dry weight between the P at $25 \mathrm{mg}$ / week and $\mathrm{P}$ at $5 \mathrm{mg} /$ week treatments combined with $\mathrm{N}$ at 250 $\mathrm{mg} /$ week $(250 \mathrm{~N}: 25 \mathrm{P}$ and $250 \mathrm{~N}: 5 \mathrm{P})$ during either year's study. In the 2002 study, there were no differences in total and shoot dry weight between the $\mathrm{N}$ treatments of $250 \mathrm{mg} /$ week and 100 $\mathrm{mg} /$ week regardless of $\mathrm{P}$ treatment. In the 2001 study, root dry weight of azaleas given the $25 \mathrm{~N}$ :0P treatment was significantly greater than the $250 \mathrm{~N}: 25 \mathrm{P}$ treatment. This result was seen again 
Table 1. Average dry weight data and root:shoot ratio in azalea (less than 2 years old) after 10 weeks of treatment $($ March to May) in 2001 ( $\mathrm{n}=5)$ and $2002(\mathrm{n}=3)^{\mathrm{z}}$

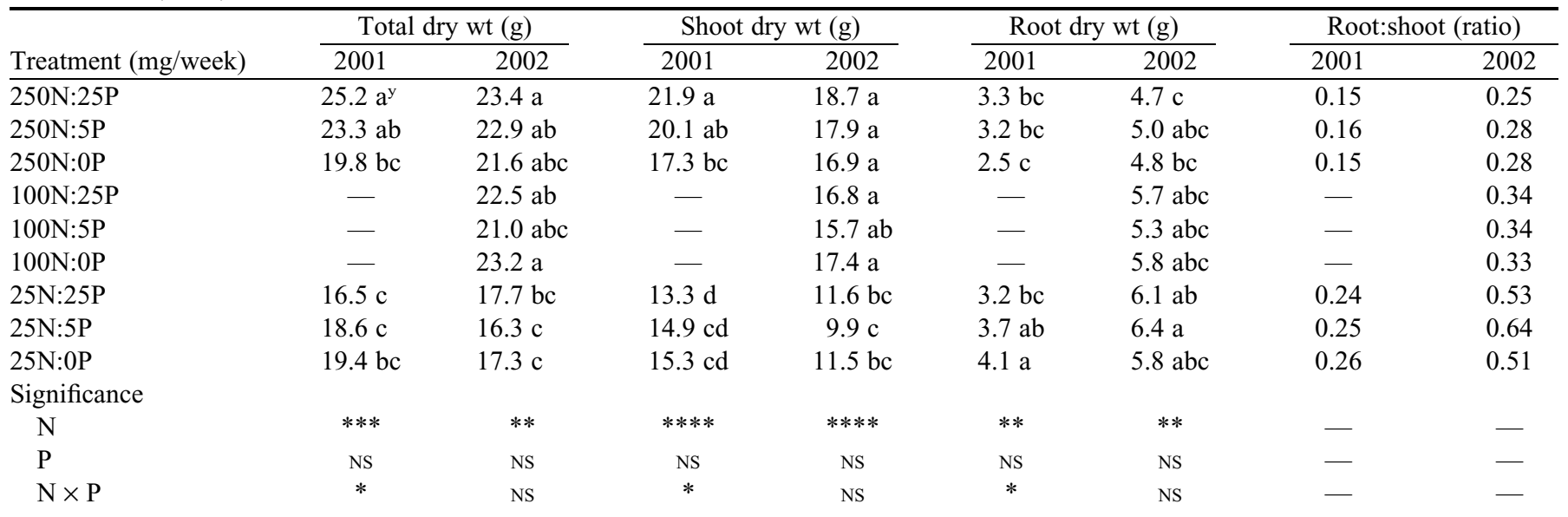

${ }^{\mathrm{z}} \mathrm{In} 2001$, azalea were fertilized 11 times over the study period, an initial and 10 weekly applications. In 2002, 18 half-rate applications were made over the study period. Lower case letters indicate significant differences (LSD at $P \leq 0.05$ ) between treatments. Total dry weight refers to total plant dry weight.

${ }^{y}$ Means within columns followed by the same letter are not significantly different $(\alpha=0.05)$ by LSD.

NS,*,**,***,***** Nonsignificant or significant at $P \leq 0.05,0.01,0.001$, or 0.0001 , respectively.

LSD $=$ least significant difference.

in the 2002 study. In fact, a trend toward decreasing root dry weight with increasing $\mathrm{N}$ rates can be noted from the 2002 root dry weight data in Table 1. Root:shoot dry weight ratios of the $\mathrm{N}$ treatments of $25 \mathrm{mg} /$ week were twice that of the $\mathrm{N}$ treatments of $250 \mathrm{mg} /$ week in both years; azalea plants given $\mathrm{N}$ treatments of $100 \mathrm{mg} /$ week were intermediate between the $\mathrm{N}$ at $250 \mathrm{mg} /$ week and $25 \mathrm{mg} /$ week in the 2002 study, showing how carbon resources are shifted in response to $\mathrm{N}$ treatment (Table 1). In general, total and shoot dry weights were not significantly increased above moderate $\mathrm{N}$ and $\mathrm{P}(100 \mathrm{~N}: 5 \mathrm{P})$ fertilization rates and root dry weights were not increased significantly above background $\mathrm{P}$ rates (essentially less than $3 \mathrm{mg}$ per week = 0 rate).

Figure $1 \mathrm{~A}, \mathrm{~B}$, and $\mathrm{C}$ compare the average dry weight partitioning of shoots (leaves, primary and secondary branches, and stems) and roots between the $250 \mathrm{~N}: 5 \mathrm{P}, 100 \mathrm{~N}: 5 \mathrm{P}$, and $25 \mathrm{~N}: 5 \mathrm{P}$ treatment combinations during the 2002 study, because there were no significant differences in total dry weight between the $P$ treatments of $25 \mathrm{mg} /$ week and $5 \mathrm{mg} /$ week (Table 1). Significant differences in total dry weight did not occur between treatments until $56 \mathrm{~d}$ into the study (fourth harvest) when the $\mathrm{N}$ rate of $25 \mathrm{mg} /$ week became limiting to growth. At $42 \mathrm{~d}$ into the study (third harvest), shoot dry weight became increasingly affected by the limiting $\mathrm{N}$ rate of $25 \mathrm{mg} / \mathrm{week}$. Although there was little significance in increased root dry weight between most treatments, by $56 \mathrm{~d}$ into the study (data not shown), azaleas given the $25 \mathrm{~N}: 5 \mathrm{P}$ treatment had accumulated significantly greater root weight than azaleas given the luxurious rates of $250 \mathrm{~N}: 25 \mathrm{P}$ per week, a treatment effect that persisted to the end of the study (Table 1).

Plant nitrogen and phosphorus. Table 2 shows average total, shoot, and root $\mathrm{N}$ contents for all treatments at the end of both studies. In both studies, total plant and shoot $\mathrm{N}$ accumulation was primarily a function of $\mathrm{N}$ rate and was significantly lower for the $\mathrm{N}$ treatments of $25 \mathrm{mg} /$ week compared with the $\mathrm{N}$ at $250 \mathrm{mg} /$ week in both studies as well as the $\mathrm{N}$ treatments of $100 \mathrm{mg} /$ week in the 2002 study (Table 2). In the 2001 study, root $\mathrm{N}$ was significantly greater in the $\mathrm{N}$ treatments of $250 \mathrm{mg} /$ week, except for the $250 \mathrm{~N}: 0 \mathrm{P}$ treatment, which was not different from any of the $\mathrm{N}$ at $25-\mathrm{mg} /$ week treatments (nitrogenlimited). In roots, $\mathrm{N}$ content was not completely a function of dry weight dynamics. Azaleas under high $\mathrm{N}$ rates had generally smaller root weight (Table 1) yet contained more $\mathrm{N}$ (Table 2), thus having much lower $\mathrm{N}$ use efficiency than root tissue of plants under low $\mathrm{N}$ rates.

Figure $2 \mathrm{~A}, \mathrm{~B}$, and $\mathrm{C}$ compares $\mathrm{N}$ partitioning among the $250 \mathrm{~N}: 5 \mathrm{P}, 100 \mathrm{~N}: 5 \mathrm{P}$, and $25 \mathrm{~N}: 5 \mathrm{P}$ treatment combinations in the 2002 study. These figures illustrate the time course of the absolute changes in $\mathrm{N}$ content between treatments during the 2002 study. A significant difference in total $\mathrm{N}$ content was evident by $14 \mathrm{~d}$ between azaleas given $\mathrm{N}$ at $25 \mathrm{mg} /$ week and $\mathrm{N}$ at $250 \mathrm{mg} /$ week. By $42 \mathrm{~d}$ into the study, significant differences in $\mathrm{N}$ content were noted between the treatments of $\mathrm{N}$ at 25,100 , and $250 \mathrm{mg} / \mathrm{week}$ and $\mathrm{P}$ at $5 \mathrm{mg} / \mathrm{week}$, but by the end of the study, azalea total $\mathrm{N}$ content between treatments of $\mathrm{N}$ at 100 and $250 \mathrm{mg} /$ week and $\mathrm{P}$ at $5 \mathrm{mg} /$ week were no longer significant. Shoot and root tissue $\mathrm{N}$ content followed similar patterns. Notably, almost two-thirds of the plant $\mathrm{N}$ content was contained within the leaf tissue of both $250 \mathrm{~N}: 5 \mathrm{P}$ and $100 \mathrm{~N}: 5 \mathrm{P}$ treatment combinations. Oddly, total $\mathrm{N}$ was significantly different between the $250 \mathrm{~N}: 25 \mathrm{P}$ and $100 \mathrm{~N}: 5 \mathrm{P}$ treatments by the end of the study and may have been the result of the lower $\mathrm{N}$ content for root tissue in the $100 \mathrm{~N}: 5 \mathrm{P}$ treatment (Table 2).

Interestingly, in both studies, plants exhibited some $\mathrm{P}$ uptake from the zero $P$ treatments with plant $P$ increasing from initial harvest levels. Analysis of substrate samples taken at the onset of the 2002 study found that an average of $29 \mathrm{mg}$ of native soluble $\mathrm{P}$ was available for each plant in addition to any other fertilization amounts. The available $\mathrm{P}$ confounded the $0-\mathrm{mg} \mathrm{P}$ treatment resulting in less clear growth data and $\mathrm{P}$ uptake results. In the $0-\mathrm{mg} P$ treatments, azaleas were able to, at least temporarily, overcome induced $\mathrm{P}$ deficiency.

In the 2001 study, $\mathrm{P}$ content was a function of both $\mathrm{N}$ and $\mathrm{P}$ rate. Total plant $\mathrm{P}$ was significantly higher in the $250 \mathrm{~N}: 25 \mathrm{P}$ 


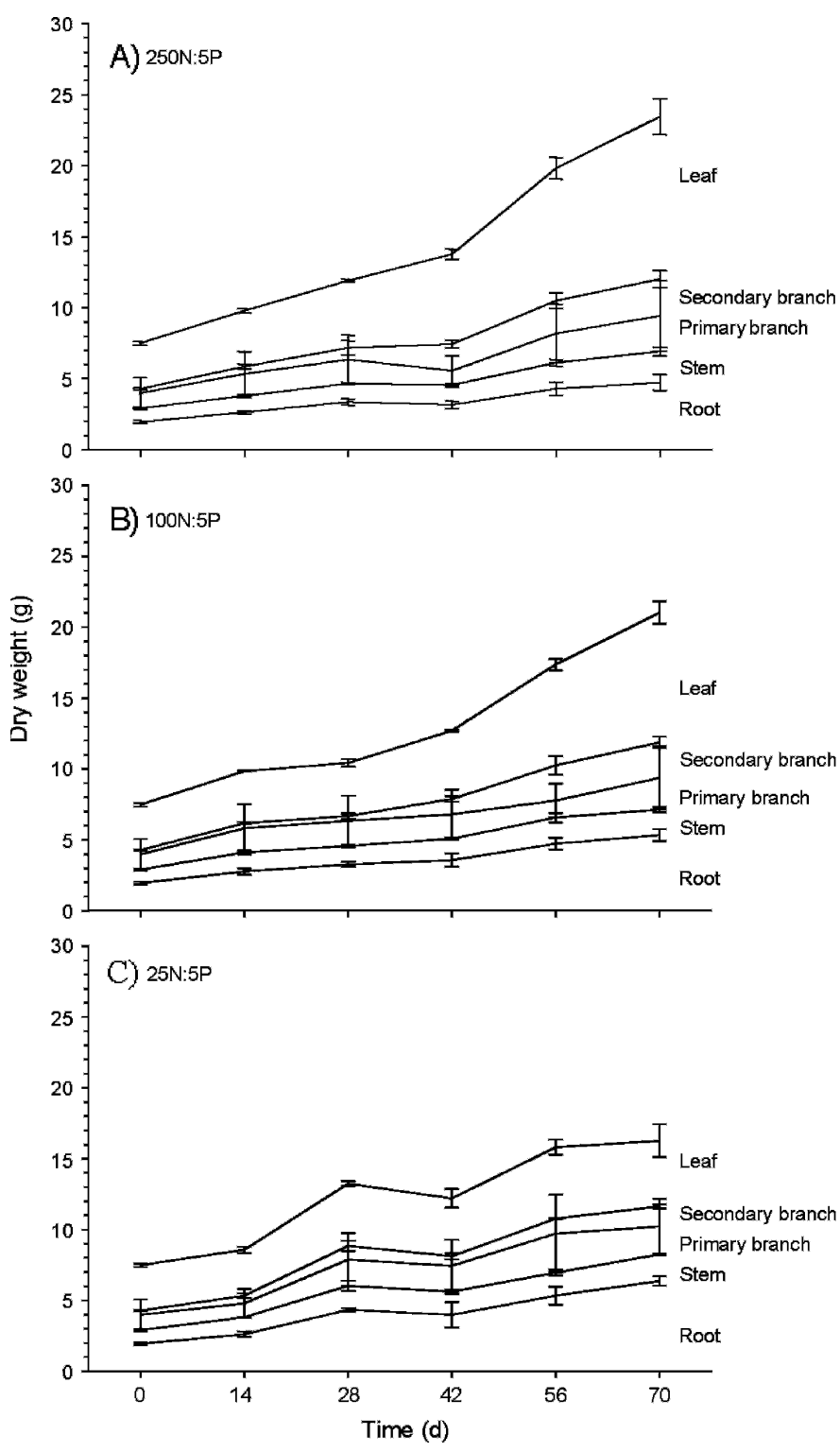

Fig. 1. Average $(n=3)$ dry weight partitioning (cumulative) of azalea root, stem, primary and secondary branch and leaves given (A) $250 \mathrm{~N}: 5 \mathrm{P},(\mathrm{B}) 100 \mathrm{~N}: 5 \mathrm{P}$, and (C) $25 \mathrm{~N}: 5 \mathrm{P} \mathrm{mg}$ /week from 25 Mar. to 20 May 2002. The top partitioning line represents total dry weight. Areas between lines represent dry weight partitioned by tissue. Error bars about the mean represent $1 \mathrm{SE}$.

treatment compared with all other treatments (Table 2). In the 2002 study, $\mathrm{P}$ content was also a function of both $\mathrm{N}$ and $\mathrm{P}$ rate but with no treatment interaction. In the 2002 study, no differences in total, shoot, or root $\mathrm{P}$ were found between the $\mathrm{P}$ treatments of $25 \mathrm{mg} /$ week and $5 \mathrm{mg} /$ week (Table 2). Only azaleas given the $250 \mathrm{~N}: 25 \mathrm{P}$ and $100 \mathrm{~N}: 25 \mathrm{P}$ treatments had significantly greater total plant $\mathrm{P}$ than azaleas given $25 \mathrm{~N}: 0 \mathrm{P}$ and $100 \mathrm{~N}: 0 \mathrm{P}$ treatments. Plants under the $250 \mathrm{~N}: 25 \mathrm{P}$ treatment accumulated nearly twice as much $P$ as the $100 \mathrm{~N}: 0 \mathrm{P}$ treatment, yet the average dry weight was not significantly different between them. Like with $\mathrm{N}$, over half of the plant $\mathrm{P}$ is partitioned into the leaf tissue. Figure $3 \mathrm{~A}, \mathrm{~B}$, and $\mathrm{C}$ compare plant tissue $\mathrm{P}$ partitioning among the $250 \mathrm{~N}: 25 \mathrm{P}, 250 \mathrm{~N}: 5 \mathrm{P}$, and $250 \mathrm{~N}$ :0P treatments. Only by the last harvest (day 70) did differences in $\mathrm{P}$ content occur between the $250 \mathrm{~N}: 25 \mathrm{P}$ and
$250 \mathrm{~N}: 0 \mathrm{P}$ treatments in shoot (leaves, primary and secondary branches, and stems) and root tissues. However, differences in $\mathrm{P}$ uptake and content began to emerge between $\mathrm{P}$ treatments with azaleas given the $\mathrm{N}$ treatments of 25 and $100 \mathrm{mg} /$ week by day 42 (data not shown).

Because there was no difference in total, shoot, or root dry weight among the three treatments, greater $\mathrm{P}$ content in the $250 \mathrm{~N}: 25 \mathrm{P}$ treatment shows luxury consumption and storage with fertilizer containing an N:P ratio of 10:1. Azaleas in the $250 \mathrm{~N}$ :25P treatment stored excess $\mathrm{P}$ mainly in leaf and root tissues. Root $\mathrm{P}$ content declined with decreasing $\mathrm{P}$ rate within each $\mathrm{N}$ treatment although there was little difference in root weight among most treatments. Consequently, the N:P ratio increased directly as a function of decreased $\mathrm{P}$ application. Higher N/P ratios were seen in the high $\mathrm{N}$ treatment combinations.

LEACHING AND UPTAKE EFFICIENCY. Differences in N leachate were the result of $\mathrm{N}$ treatment alone (Table 3 ). As $\mathrm{N}$ fertilization rate increased, significantly greater amounts of $\mathrm{N}$ leached from containers. In the 2002 study, 40 times less $\mathrm{N}$ was leached from the $\mathrm{N}$ treatments of $25 \mathrm{mg} /$ week, and up to four times less $\mathrm{N}$ was leached from the $\mathrm{N}$ treatments of $100 \mathrm{mg} /$ week, compared with the $\mathrm{N}$ treatments of $250 \mathrm{mg} /$ week (Table 3).

Differences in $\mathrm{P}$ leachate were the result of interactive effects between $\mathrm{N}$ and $\mathrm{P}$ treatment in only the 2001 study. In general, higher $\mathrm{P}$ fertilization significantly increased $\mathrm{P}$ leachate. Oddly, the $250 \mathrm{~N}: 25 \mathrm{P}$ treatment averaged significantly less leachate than either the $100 \mathrm{~N}: 25 \mathrm{P}$ or $25 \mathrm{~N}: 25 \mathrm{P}$ treatments, despite no obvious differences in growth between the $250 \mathrm{~N}$ and $100 \mathrm{~N}$ treatments. Compared with lower nutrient treatment rates, a substantial amount of $\mathrm{N}$ and $\mathrm{P}$ remained in the substrates of the high $\mathrm{N}$ and $\mathrm{P}$ treatment rates on completion of both studies (Table 3).

In both studies, $\mathrm{N}$ uptake efficiency decreased as $\mathrm{N}$ application rate increased and this relationship was more pronounced for $\mathrm{P}$ uptake efficiency (Table 3). In the 2002 study, average $\mathrm{N}$ uptake efficiencies were significantly greater in azaleas under the $\mathrm{N}$ at $25 \mathrm{mg} /$ week than the $\mathrm{N}$ at $250 \mathrm{mg} /$ week. Average $\mathrm{N}$ uptake efficiencies for azaleas under the $\mathrm{N}$ at $100 \mathrm{mg} /$ week were intermediary between the high and low $\mathrm{N}$ treatments. The $\mathrm{P}$ uptake efficiency of azaleas under the $\mathrm{P}$ treatment of $5 \mathrm{mg} /$ week increased threefold over azalea given $25 \mathrm{mg} /$ week of $\mathrm{P}$.

\section{Discussion}

With regard to the rates used in this study, it should be noted that many growers consider rates of 150 to $200 \mathrm{mg} \cdot \mathrm{L}^{-1} \mathrm{~N}$ as a "low" N rate, which, if applied as a constant feed (say applying $500 \mathrm{~mL}$ fertilizer per day) equates to $\mathrm{N}$ rates between 525 and $700 \mathrm{mg} / \mathrm{plant}$ per week. This gives a perspective on the rates used in these studies, the highest rate being $\mathrm{N}$ at $250 \mathrm{mg} / \mathrm{plant}$ per week. Alternatively, many controlled-release fertilizer manufacturers make rate recommendations based on container size. Nitrogen rates of $100 \mathrm{mg} /$ week is considered low for the Custom \#2 containers used in this study. For example, the $\mathrm{N}$ rate of $100 \mathrm{mg} /$ week is similar to applying $22 \mathrm{~g}$ of an $18 \%$ nitrogen fertilizer over a 40-week growing season.

The $250 \mathrm{mg} /$ week $\mathrm{N}$ rates promoted more pronounced differences in shoot growth compared with root growth of azalea in both studies. More importantly, the "intermediate" $\mathrm{N}$ rate of $100 \mathrm{mg} /$ week adequately maintained optimal growth 
Table 2. Average nitrogen and phosphorus content (= concentration $\times$ dry weight) in azalea (less than 2 years old) tissues after 10 weeks of treatment (March to May) in $2001(\mathrm{n}=5)$ and $2002(\mathrm{n}=3) .^{\mathrm{z}}$

\begin{tabular}{|c|c|c|c|c|c|c|c|c|c|c|c|c|}
\hline \multirow{2}{*}{$\begin{array}{l}\text { Treatment } \\
\text { (mg/week) }\end{array}$} & \multicolumn{2}{|c|}{ Total plant N (mg) } & \multicolumn{2}{|c|}{ Shoot N (mg) } & \multicolumn{2}{|c|}{ Root N (mg) } & \multicolumn{2}{|c|}{ Total plant P (mg) } & \multicolumn{2}{|c|}{ Shoot P (mg) } & \multicolumn{2}{|c|}{ Root P (mg) } \\
\hline & 2001 & 2002 & 2001 & 2002 & 2001 & 2002 & 2001 & 2002 & 2001 & 2002 & 2001 & 2002 \\
\hline $250 \mathrm{~N}: 25 \mathrm{P}$ & $523.2 \mathrm{a}^{\mathrm{y}}$ & $428.9 \mathrm{a}$ & $455.1 \mathrm{a}$ & $332.7 \mathrm{a}$ & $68.0 \mathrm{a}$ & $96.1 \mathrm{a}$ & $62.7 \mathrm{a}$ & $50.5 \mathrm{a}$ & $52.5 \mathrm{a}$ & $39.6 \mathrm{a}$ & $10.2 \mathrm{a}$ & $10.9 \mathrm{ab}$ \\
\hline $250 \mathrm{~N}: 5 \mathrm{P}$ & $442.9 \mathrm{ab}$ & $380.3 \mathrm{ab}$ & $383.4 \mathrm{ab}$ & $299.2 \mathrm{a}$ & $59.6 \mathrm{a}$ & $81.1 \mathrm{ab}$ & $43.3 \mathrm{~b}$ & $40.8 \mathrm{ab}$ & $38.1 \mathrm{~b}$ & $32.2 \mathrm{ab}$ & $5.2 \mathrm{c}$ & $8.6 \mathrm{bc}$ \\
\hline $100 \mathrm{~N}: 25 \mathrm{P}$ & - & $355.3 \mathrm{ab}$ & - & $284.2 \mathrm{a}$ & - & $71.2 \mathrm{abc}$ & - & $52.7 \mathrm{a}$ & - & $38.0 \mathrm{a}$ & - & $14.7 \mathrm{a}$ \\
\hline $100 \mathrm{~N}: 5 \mathrm{P}$ & - & $326.2 \mathrm{~b}$ & - & $262.5 \mathrm{a}$ & 一 & $63.7 \mathrm{~b}$ & - & $41.1 \mathrm{ab}$ & - & $30.0 \mathrm{ab}$ & - & $11.1 \mathrm{ab}$ \\
\hline $25 \mathrm{~N}: 5 \mathrm{P}$ & $152.4 \mathrm{c}$ & $186.8 \mathrm{c}$ & $124.8 \mathrm{c}$ & $127.0 \mathrm{~b}$ & $27.7 \mathrm{~b}$ & $59.8 \mathrm{bc}$ & $46.2 \mathrm{~b}$ & $37.0 \mathrm{ab}$ & $39.3 \mathrm{~b}$ & $23.9 \mathrm{~b}$ & $6.9 \mathrm{bc}$ & $13.1 \mathrm{ab}$ \\
\hline $25 \mathrm{~N}: 0 \mathrm{P}$ & $216.4 \mathrm{c}$ & $177.9 \mathrm{c}$ & $182.6 \mathrm{c}$ & $126.6 \mathrm{~b}$ & $33.9 \mathrm{~b}$ & $51.3 \mathrm{c}$ & $28.1 \mathrm{c}$ & $31.9 \mathrm{~b}$ & $22.4 \mathrm{c}$ & $22.0 \mathrm{~b}$ & $5.7 \mathrm{c}$ & $9.9 \mathrm{bc}$ \\
\hline \multicolumn{13}{|c|}{ Significance } \\
\hline $\mathrm{N}$ & $* * * *$ & $* * * *$ & $* * * *$ & $* * * *$ & $* * * *$ & $* *$ & $* * * *$ & NS & NS & $* *$ & NS & $*$ \\
\hline $\mathrm{P}$ & NS & NS & NS & NS & NS & NS & $* *$ & $* *$ & $* * * *$ & NS & $* * * *$ & $* *$ \\
\hline $\mathrm{N} \times \mathrm{P}$ & NS & NS & NS & NS & $* *$ & NS & $*$ & NS & NS & NS & $* *$ & NS \\
\hline
\end{tabular}

${ }^{\mathrm{z}}$ Shoot tissues include leaf and branches and stem. Lower case letters indicate significant differences (LSD at $\left.P \leq 0.05\right)$ between treatments. ${ }^{\mathrm{y}}$ Means within columns followed by the same letter are not significantly different $(\alpha=0.05)$ by LSD.

Ns, ${ }^{* * *, * * *, * * * *}$ Nonsignificant or significant at $P \leq 0.05,0.01,0.001$, or 0.0001 , respectively.

LSD $=$ least significant difference.

rates compared with the "high" fertilization rates in these studies. Additionally, these treatments needed no more than very low amounts of $\mathrm{P}(5 \mathrm{mg} /$ week $)$ to overcome a P limitation on growth. In the 2002 study, adequate nutrient rates of $100 \mathrm{~N}: 5 \mathrm{P}$ maintained total dry weight and shoot dry weight no different from the higher fertilization rates. Cabrera (2003) noted similar results in Ilex opaca Ait. 'Hedgeholly' and Lagerstroemia L. 'Tonto' with respect to $\mathrm{N}$ rate on root and shoot growth. For both species, an $\mathrm{N}$ rate of $60 \mathrm{mg} \cdot \mathrm{L}^{-1}$ applied two to four times weekly was sufficient to maintain growth compared with higher $\mathrm{N}$ concentrations. Cabrera's $\mathrm{N}$ rate of $60 \mathrm{mg} \cdot \mathrm{L}^{-1}$ converts to an approximate $\mathrm{N}$ rate of $50 \mathrm{mg} / \mathrm{week}$.

Despite having a "zero" P treatment in 2002, no differences in total dry weight were seen between any $\mathrm{P}$ treatment combinations for either $\mathrm{N}$ rate of 250 or $100 \mathrm{mg}$ /week during this study. This was the result of native $\mathrm{P}$ in the uncomposted pine bark, which was estimated to be between 24 and $30 \mathrm{mg}$ of total available $\mathrm{P}$. From the results, this native $\mathrm{P}$ was sufficient to maintain adequate growth of azalea, at least over the short term.

The response of root growth was quite different and was contradictory to the conventional view that high P fertilization increases root growth (Harris, 1992). The greatest root:shoot ratios were with the $25 \mathrm{mg}$ /week (low) $\mathrm{N}$ treatments because shoot growth was limited by available N. In the first study, the greatest root dry weight was seen in the $25 \mathrm{~N}: 0 \mathrm{P}$ treatment; whereas root growth was reduced without $\mathrm{P}$ in the $250 \mathrm{~N}: 0 \mathrm{P}$ treatment, this was not significantly different from any high $\mathrm{N}$ treatment or the $25 \mathrm{~N}: 25 \mathrm{P}$ treatment, again perhaps as a result of native $\mathrm{P}$ in the substrate. Thus, in azalea (a low nutrient use species), root weight is not improved with high $\mathrm{P}$ fertilization but increases under conditions of low nutrient concentration as has noted by other authors for other plant species (Borch et al., 1998; Hansen and Lynch, 1998; Lynch et al., 1991; Yeager and Wright, 1981; Zhang et al., 2002). In the second study, P treatments had no effect on root growth, most likely attributable to the presence of adequate amounts of plant-available $\mathrm{P}$ in the substrate throughout the study. Sufficient rates of both $\mathrm{N}$ and $\mathrm{P}$ $(100 \mathrm{~N}: 5 \mathrm{P})$ sustained root growth that was no different from the $\mathrm{N}$ treatments of $25 \mathrm{mg} /$ week. A comparatively larger average root weight was found with low $\mathrm{N}$ treatments. Fertilization recommendations commonly focus on promoting maximum shoot growth in plants. By using more moderate $\mathrm{N}$ rates, more optimal root/shoot ratios can be maintained, which may improve nutrient uptake efficiencies while in production and promote greater postplanting survival rate in the landscape.

Although supplying the azalea with high $\mathrm{N}$ and $\mathrm{P}$ rates increased plant nutrient contents, greater quantities of residual substrate $\mathrm{N}$ and $\mathrm{P}$ were available for loss through leaching and perhaps other loss mechanisms. There was a surprisingly large quantity of residual $\mathrm{N}$ and $\mathrm{P}$ left in substrates at the end of the study, especially from the high $\mathrm{N}$ and $\mathrm{P}$ treatments (Table 3 ). Although Marconi and Nelson (1984) concluded that soilless mixes had low $\mathrm{P}$ adsorption capacity and $\mathrm{PO}_{4}{ }^{-3}$ ions could leach easily from these types of substrate, they also found in some cases that P did not leach out in expected quantities. Marconi and Nelson (1984) found that irrigation water did not achieve $100 \%$ displacement throughout the substrate and that the applied water channeled through macropores, leaching out only portions of applied P. It is reasonable to suspect that this may have occurred during this study with both $\mathrm{N}$ and $\mathrm{P}$. Additionally, azalea roots did not completely explore the container volume during the study, leaving areas within the container untouched by root activity.

In both studies, average $\mathrm{P}$ leachate was greatest in the $25 \mathrm{~N}: \mathrm{P} 25$ treatment, most likely as a result of the N growth limitation; consequently, the applied $\mathrm{P}$ was not fully used by the plant. In the 2001 study, there was some P leachate from the zero $\mathrm{P}$ treatments, perhaps as a result of root turnover or the release of native $\mathrm{P}$ by the pine bark substrate. An even greater amount of available P was found in the second study's substrate in amounts enough to sustain growth without $\mathrm{P}$ fertilization. This may have been because substrate was not well composted (as evidenced by the manganese problem). In fact, the second highest average dry weight was sampled from the $100 \mathrm{~N}: 0 \mathrm{P}$ treatment. Despite many publications pointing to the contrary (Gutschick and Kay, 1995; Hansen and Lynch, 1998; Lynch et al., 1991), the belief that it is necessary to apply more than minimal quantities of $\mathrm{P}$ to promote root development seems to 


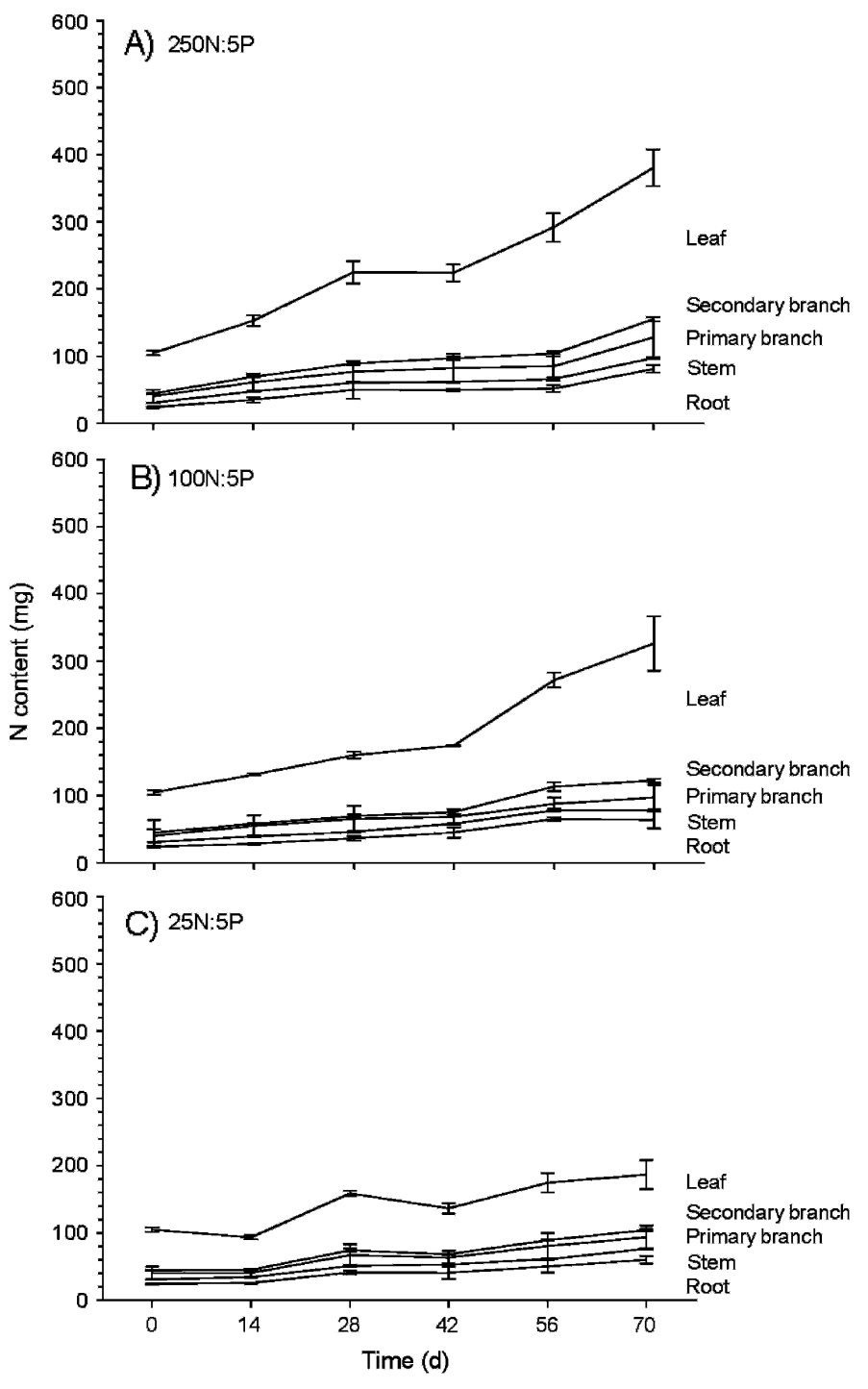

Fig. 2. Average $(n=3)$ nitrogen partitioning (cumulative) of azalea root, stem, primary and secondary branch and leaves given (A) $250 \mathrm{~N}: 5 \mathrm{P}$, (B) $100 \mathrm{~N}: 5 \mathrm{P}$, and (C) $25 \mathrm{~N}: 5 \mathrm{P} \mathrm{mg}$ /week from 25 Mar. to 20 May 2002. The top partitioning line represents total $\mathrm{N}$ content. Areas between lines represent $\mathrm{N}$ partitioned by tissue. Error bars about the mean represent $1 \mathrm{SE}$.

be common in the nursery industry. Fertilizers containing near equimolar ratios of $\mathrm{N}$ and $\mathrm{P}$ claim to boost root growth. The results presented here add to the growing literature disputing these assertions. Because no differences in growth were noted with either P treatment of $25 \mathrm{mg} /$ week or $5 \mathrm{mg} /$ week, optimal P rates should be between 0 and $5 \mathrm{mg} /$ week for young azalea.

Nutrient uptake efficiency was affected primarily by the amount of nutrient applied. The plants under the highest nutrient ( $250 \mathrm{mg} \mathrm{N}$ or $25 \mathrm{mg} \mathrm{P}$ ) regimes only used between $11 \%$ and $16 \%$ of the total $\mathrm{N}$ and $\mathrm{P}$ applied in both studies. Plant uptake efficiencies for $\mathrm{N}$ and $\mathrm{P}$ were two to four times greater with lower rates of both $\mathrm{N}$ and $\mathrm{P}$, indicating that fertilization rates were in excess of immediate, but not necessarily longterm, plant requirements. Interestingly, Sandrock et al. (2005) suggest that uptake efficiencies for lower nutrient rates may be overestimated as a result of available nutrients in the soilless potting substrate. Available $\mathrm{N}$ in the soilless potting substrate at initiation of the 2002 study was no more than $8 \mathrm{mg}$ per plant
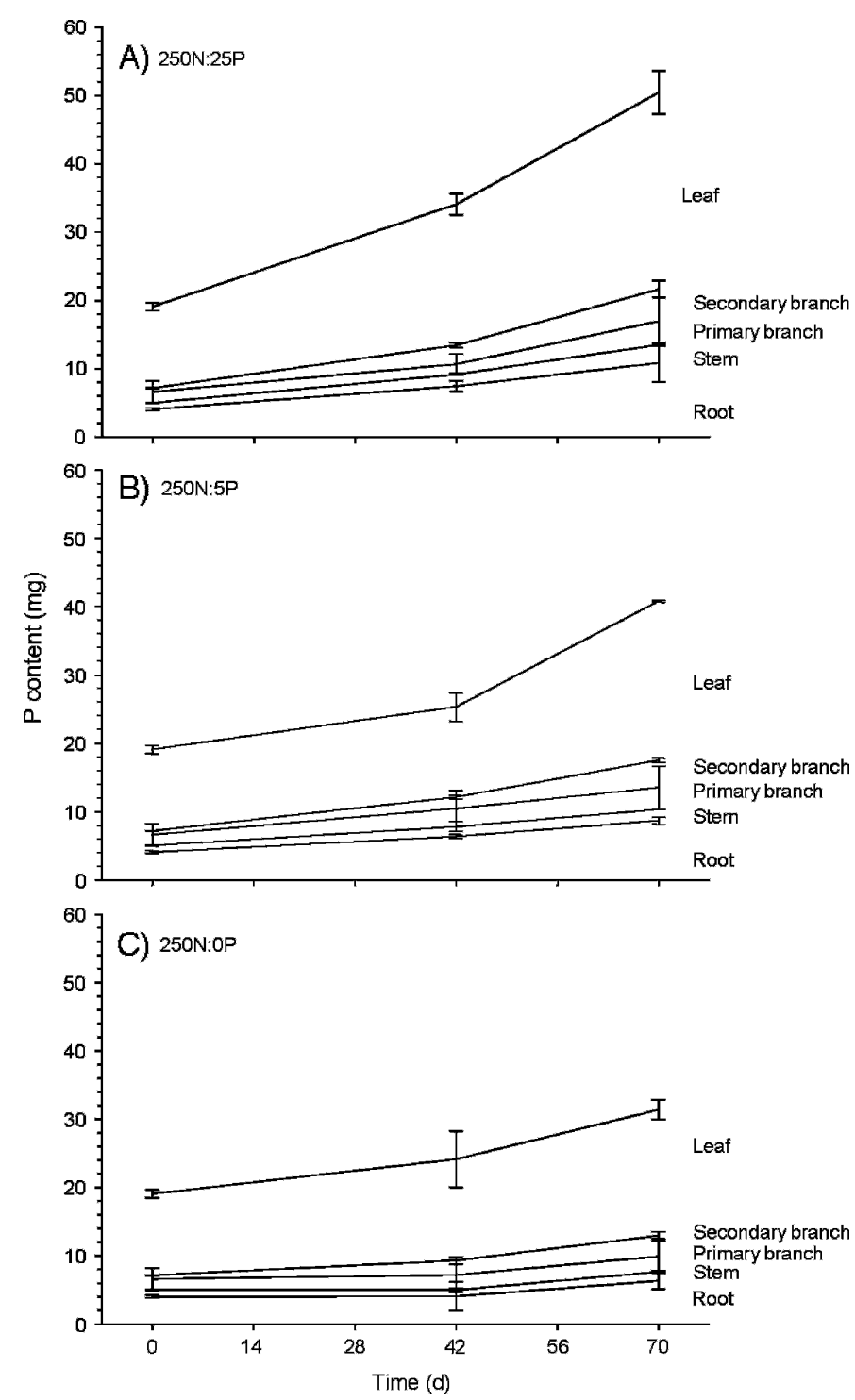

Fig. 3. Average $(n=3)$ phosphorus partitioning (cumulative) of azalea root, stem, primary and secondary branch and leaves given (A) $250 \mathrm{~N}: 25 \mathrm{P}$, (B) 250N:5P, and (C) 250N:0P mg/week from 25 Mar. to 20 May 2002. Results shown are from day 0 , day 42 , and day 70 harvests. The top partitioning line represents total $\mathrm{P}$ content. Areas between lines represent $\mathrm{P}$ partitioned by tissue. Error bars about the mean represent $1 \mathrm{SE}$.

container and when added to the budget had a negligible effect on $\mathrm{N}$ uptake efficiencies for all rates. Initial soluble $\mathrm{P}$ was $\approx 29$ $\mathrm{mg} /$ container. Consequently, recalculating P uptake efficiencies in Table 3 by the addition of this $29 \mathrm{mg}$ available $\mathrm{P}$ would have lowered efficiencies by less than $1.5 \%$ in the high $\mathrm{P}$ treatments of $25 \mathrm{mg} /$ week. Phosphorus uptake efficiencies would have dropped to $\approx 20 \%$ for azaleas given the sufficient $P$ rate of $5 \mathrm{mg} /$ week compared with the calculated range of $40.1 \%$ to $49.2 \%$ (Table 3 ). Interestingly, the uptake efficiencies from the no-P rates would have been between $42 \%$ and $59 \%$. However, given the variability of readily available nutrients in various soilless potting media, it would not be advisable to base nutrient fertility on potential nutrient availability, because pine bark substrates are extremely variable.

The results of Sandrock et al. (2005) suggest that bound N may be mineralized in soilless potting media, which may lead to 
Table 3. Nutrient uptake and nutrient budget for azalea (less than 2 years old) after 10 weeks of treatment (March to May) in 2001 ( $\mathrm{n}=5)$ and $2002(\mathrm{n}=3)^{\mathrm{z}}$

\begin{tabular}{|c|c|c|c|c|c|c|c|c|c|c|c|c|c|c|c|c|}
\hline \multirow{2}{*}{$\begin{array}{l}\text { Treatment } \\
\text { (mg/week) }\end{array}$} & \multicolumn{2}{|c|}{$\begin{array}{l}\text { Plant N uptake } \\
(\mathrm{mg})\end{array}$} & \multicolumn{2}{|c|}{$\begin{array}{l}\text { N Leachate } \\
(\mathrm{mg})\end{array}$} & \multicolumn{2}{|c|}{$\begin{array}{l}\text { Substrate N } \\
(\mathrm{mg})\end{array}$} & \multicolumn{2}{|c|}{$\begin{array}{c}\mathrm{N} \text { uptake } \\
\text { efficiency }(\%)\end{array}$} & \multicolumn{2}{|c|}{$\begin{array}{c}\text { Plant P } \\
\text { uptake }(\mathrm{mg})\end{array}$} & \multicolumn{2}{|c|}{$\begin{array}{l}\text { P Leachate } \\
(\mathrm{mg})\end{array}$} & \multicolumn{2}{|c|}{$\begin{array}{l}\text { Substrate } \\
\mathrm{P}(\mathrm{mg})\end{array}$} & \multicolumn{2}{|c|}{$\begin{array}{c}\text { P uptake } \\
\text { efficiency }(\%)\end{array}$} \\
\hline & 2001 & 2002 & 2001 & 2002 & 2001 & 2002 & 2001 & 2002 & 2001 & 2002 & 2001 & 2002 & 2001 & 2002 & 2001 & 2002 \\
\hline $250 \mathrm{~N}: 25 \mathrm{P}$ & $431.6 \mathrm{a}^{\mathrm{y}}$ & $324.9 \mathrm{a}$ & $84.2 \mathrm{a}$ & $117.1 \mathrm{~b}$ & 695.6 & 762.6 & $15.8 \mathrm{bc}$ & $14.4 \mathrm{bc}$ & $41.8 \mathrm{a}$ & $31.5 \mathrm{a}$ & $5.4 \mathrm{~b}$ & $8.3 \mathrm{~b}$ & 25.8 & 83.1 & $15.2 \mathrm{~b}$ & $\overline{14.0 \mathrm{~b}}$ \\
\hline $250 \mathrm{~N}: 0 \mathrm{P}$ & 309.6 b & $313.4 \mathrm{ab}$ & 106.7 a & $147.6 \mathrm{a}$ & 670.6 & 897.1 & $11.1 \mathrm{c}$ & $13.9 \mathrm{bc}$ & $0.5 \mathrm{c}$ & $12.4 \mathrm{~b}$ & $2.9 \mathrm{c}$ & $2.0 \mathrm{c}$ & 7.2 & 9.9 & - & - \\
\hline $100 \mathrm{~N}: 25 \mathrm{P}$ & - & $251.3 \mathrm{ab}$ & - & $35.6 \mathrm{c}$ & - & 169.2 & - & $27.9 \mathrm{ab}$ & - & $33.7 \mathrm{a}$ & - & $13.8 \mathrm{a}$ & - & 64.4 & - & $15.0 \mathrm{~b}$ \\
\hline $100 \mathrm{~N}: 5 \mathrm{P}$ & - & $222.2 \mathrm{~b}$ & - & $44.2 \mathrm{c}$ & - & 92.9 & - & $24.7 \mathrm{abc}$ & - & $22.1 \mathrm{ab}$ & - & $2.7 \mathrm{c}$ & - & 16.4 & - & $49.2 \mathrm{a}$ \\
\hline $25 \mathrm{~N}: 25 \mathrm{P}$ & $54.9 \mathrm{c}$ & $4.0 \mathrm{c}$ & $9.7 \mathrm{~b}$ & $5.3 \mathrm{~d}$ & 10.9 & 8.6 & $20.9 \mathrm{abc}$ & $37.3 \mathrm{a}$ & $30.7 \mathrm{~b}$ & $24.3 \mathrm{ab}$ & $9.1 \mathrm{a}$ & $16.3 \mathrm{a}$ & 48.3 & 66.6 & $11.2 \mathrm{~b}$ & $10.8 \mathrm{~b}$ \\
\hline $25 \mathrm{~N}: 5 \mathrm{P}$ & $60.9 \mathrm{c}$ & $82.8 \mathrm{c}$ & $12.7 \mathrm{~b}$ & $3.6 \mathrm{~d}$ & 6.9 & 6.7 & $23.2 \mathrm{ab}$ & $36.8 \mathrm{a}$ & $25.2 \mathrm{~b}$ & $18.0 \mathrm{ab}$ & $3.9 \mathrm{bc}$ & $5.1 \mathrm{bc}$ & 15.3 & 24.1 & $45.9 \mathrm{a}$ & $40.1 \mathrm{a}$ \\
\hline $25 \mathrm{~N}: 0 \mathrm{P}$ & $80.2 \mathrm{c}$ & $73.9 \mathrm{c}$ & $22.0 \mathrm{~b}$ & $3.8 \mathrm{~d}$ & 14.5 & 12.3 & $31.2 \mathrm{a}$ & $32.8 \mathrm{a}$ & $7.2 \mathrm{c}$ & $13.0 \mathrm{~b}$ & $2.7 \mathrm{c}$ & $2.5 \mathrm{c}$ & 6.5 & 10.8 & - & - \\
\hline \multicolumn{17}{|l|}{ Significance } \\
\hline $\mathrm{N}$ & $* * * *$ & $* * * *$ & $* * * *$ & $* * * *$ & - & - & $* * *$ & $* * *$ & $* * * *$ & NS & $* *$ & NS & - & - & NS & NS \\
\hline $\mathrm{P}$ & NS & NS & NS & NS & - & - & NS & NS & $* *$ & $* *$ & $* * * *$ & $* * * *$ & - & - & $* * * *$ & **** \\
\hline
\end{tabular}

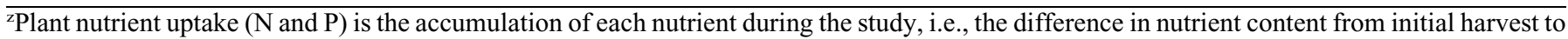
final harvest. Nitrogen and $\mathrm{P}$ uptake efficiency is the percentage of applied nutrient that was taken up after 11 or 18 (half rate) applications in 2001 and 2002, respectively. Lower case letters indicate significant differences (LSD at $P \leq 0.05$ ) between treatments.

${ }^{\mathrm{y}}$ Means within columns followed by the same letter are not significantly different $(\alpha=0.05)$ by LSD.

NS,****,***,**** Nonsignificant or significant at $P \leq 0.05,0.01,0.001$, or 0.0001 , respectively.

LSD $=$ least significant difference.

erroneous $\mathrm{N}$ uptake efficiencies at low $\mathrm{N}$ rates as in the case of $\mathrm{P}$ in this experiment. To what extent the $\mathrm{N}$ mineralization process affected the uptake efficiencies in this study was not identified. Conversely, there is also evidence in the literature that $\mathrm{N}$ drawdown in soilless media leads to a high percentage of $\mathrm{N}$ immobilized and denitrified by microorganisms (Cabrera, 2003; Handreck and Black, 1994; Ristvey, 2004; Scagel, 2003) or volatilized (Rathier and Frink, 1989). This is manifested as unrecoverable $\mathrm{N}$ during mass balance studies such as these.

The study's efficiency results should be placed in context of nutrient loading rates to the environment. A nutrient application $\mathrm{N}$ rate of $250 \mathrm{mg} / \mathrm{plant}$ per week translates into a rate of 1100 $\mathrm{kg} \cdot \mathrm{ha}^{-1}$ per year, which is half the standard rate cited by Chen et al. (2001) for azalea. We assume a 40 -week production cycle and 110,000 plants per hectare, which is a normal production density for 7.6- $\mathrm{L}$ containers in the industry. If uptake efficiencies for $\mathrm{N}$ at this rate average no more $16 \%$, then $924 \mathrm{~kg} \cdot \mathrm{ha}^{-1}$ [i.e., $\left.1100 \mathrm{~kg} \cdot \mathrm{ha}^{-1} \times(1-0.16)\right]$ potentially could be lost through leaching and other loss mechanisms such as denitrification. By reducing $\mathrm{N}$ fertilization rates to $100 \mathrm{mg} /$ plant per week, we have shown that $\mathrm{N}$ uptake efficiency increases to an average of $26.5 \%$, so under the same assumptions, only $440 \mathrm{~kg} \cdot \mathrm{ha}^{-1}$ is applied per growing season. Potential $\mathrm{N}$ loss is therefore reduced to $326 \mathrm{~kg} \cdot \mathrm{ha}^{-1}[440 \mathrm{~kg} / \mathrm{ha} \times(1-0.26)]$, resulting in a nearly threefold decrease in potential $\mathrm{N}$ loss to the environment. Using the same logic, even greater reductions in $\mathrm{P}$ loading might be achieved by decreasing $P$ rates to levels more attuned to actual plant requirements (22 vs. $\left.110 \mathrm{~kg} \cdot \mathrm{ha}^{-1}\right)$.

In summary, the results of these studies show that phosphorus fertility in azalea should be based on an $\mathrm{N}$ rate that is sufficient for growth and one that stimulates higher uptake efficiencies. In this study, an N:P ratio of 20 to 1 (100N:5P) was sufficient for 12- to 18-month-old azalea. Although limiting quantities of both $\mathrm{N}$ and $\mathrm{P}$ tend to increase root growth in azalea up to a point, a "sufficient" application rate of $100 \mathrm{mg} \mathrm{N}$ and $5 \mathrm{mg}$ P per week maintained shoot and root growth at or near maximal rates. Although the effects of the second study's $\mathrm{P}$ treatments may have been confounded by native $\mathrm{P}$ in the substrate, these results show that only very low continuous concentrations of $\mathrm{P}$ are needed to support growth of young azalea. Many standard fertilizer formulas have N:P ratios well in excess of plant $P$ requirements. It is important to recognize that azalea is a low nutrient user as an ericaceous perennial. These rates may therefore represent minimal levels necessary to support general azalea plant growth in containers at this initial stage of production.

\section{Literature Cited}

Anghinoni, I. and S.A. Barber. 1980. Phosphorus influx and growth characteristics of corn roots as influenced by phosphorus supply. Agron. J. 72:685-688.

Borch, K., K.M. Brown, and J.P. Lynch. 1998. Improvement of bedding plant quality and stress resistance with low phosphorus. HortTechnology 8:575-579.

Broschat, T.K. and A. Klock-Moore. 2000. Root and shoot growth responses to phosphate fertilization in container-grown plants. HortTechnology 10:765-767.

Cabrera, R. 2003. Nitrogen balance for two container-grown woody ornamental plants. Scientia Hort. 97:297-308.

Cabrera, R. and D.R. Devereaux. 1998. Effects of nitrogen supply on growth and nutrient status of containerized crape myrtle. J. Environ. Hort. 16:98-104.

Chen, J., Y. Huang, and R.D. Caldwell. 2001. Best management practices for minimizing nitrate leaching from container-grown nurseries. In: Optimizing nitrogen management in food and energy production and environmental protection. Proceedings of the 2 nd International Nitrogen Conference on Science and Policy. The Scientific World 1(S2):96-102.

Clesceri, L.S., A.E. Greenburg, and R.R. Trussel. 1989. Standard: methods for the examination of water and wastewater. 17th ed. Amer. Public Health Assn., Washington DC.

Craig, J.L., B.A. Birrenkott, and D.K. Struve. 2003. Nutrient uptake and dry weight patterns of three container-grown woody species. J. Environ. Hort. 21:209-215. 
Drew, M.C. and L.R. Saker. 1978. Nutrient supply and the growth of the seminal root system in barley. III. Compensatory increase in growth of lateral roots, and in rates of phosphate uptake, in response to localized supply of phosphate. J. Expt. Bot. 29:435-451.

Dufault, R.J. 1985. Relationship among nitrogen, phosphorus, and potassium fertility regimes on celery transplant growth. HortScience 20:1104-1106.

Dufault, R.J. and J.R. Schultheis. 1994. Bell pepper seedling growth and yield following pre-transplant nutritional conditioning. HortScience 29:999-1001.

Griffin, J.J., S.L. Warren, F.A. Blazich, and T.G. Ranney. 1999. Nitrogen nutrition of containerized Thuja × 'Green Giant.' J. Environ. Hort. 17:76-79.

Gutschick, V.P. and L.E. Kay. 1995. Nutrient limited growth rates: Quantitative benefits of stress responses and some aspects of regulation. J. Expt. Bot. 46:995-1009.

Handreck, K.A. and N.D. Black. 2002. Growing media for ornamental plants and turf. 3rd ed. University of New South Whales Press, Randwick, Australia.

Hansen, C.W. and J. Lynch. 1998. Response to phosphorus availability during vegetative and reproductive growth of chrysanthemum. II. Biomass and phosphorus dynamics. J. Amer. Soc. Hort. Sci. 123:223-229.

Harris, R.W. 1992. Root:shoot ratios. J. Arboriculture 18:39-42.

$\mathrm{Ku}$, C.S.M. and D.R. Hershey. 1992. Leachate electrical conductivity and growth of potted geranium with leaching fractions of 0 to 0.4 . J. Amer. Soc. Hort. Sci. 117:893-897.

Lamaze, T., F. Pashe, and A. Pornon. 2003. Uncoupling nitrogen requirements for spring growth from root uptake in a young evergreen shrub (Rhododendron ferrugineum). New Phytol. 159: 637-644.

Lin, Y.L., E.J. Holcomb, and J.P. Lynch. 1996. Marigold growth and phosphorus leaching in a soilless medium amended with phosphorus charged alumina. HortScience 31:94-98.

Lynch, J., A. Lauchli, and E. Epstein. 1991. Vegetative growth of the common bean in response to phosphorus nutrition. Crop Sci. 31: 380-387.

Marconi, D.J. and P.V. Nelson. 1984. Leaching of applied phosphorus in container media. Scientia Hort. 22:275-285.

Marschner, H. 1995. Mineral nutrition of higher plants. 2nd ed. Academic Press, San Diego.

Melton, R.R. and R.J. Dufault. 1991. Nitrogen, phosphorus, and potassium fertility regimes affect tomato transplant growth. HortScience 26:141-142.
Pasche, F., A. Pornon, and T. Lamaze. 2002. Do mature leaves provide a net source of supporting shoot growth in Rhododendron ferrugineum? New Phytol. 154:99-105.

Rathier, T.M. and C.R. Frink. 1989. Nitrate in runoff water from container grown juniper and Alberta spruce under different irrigation and $\mathrm{N}$ fertilization regimes. J. Environ. Hort. 7:32-35.

Ristvey, A.G. 2004. Water and nutrient dynamics in container-nursery production systems. University of Maryland, College Park., PhD Diss.

Rose, M.A., J.W. White, and M.A. Rose. 1994. Maximizing nitrogenuse efficiency in relation to the growth and development of poinsettia. HortScience 29:272-276.

Sandrock, D.R., T.L. Righetti, and A.N. Azarenko. 2005. Isotopic and nonisotopic estimation of nitrogen uptake efficiency in container grown woody ornamentals. HortScience 40:665-669.

Scagel, C.F. 2003. Growth and nutrient use of ericaceous plants grown in media amended with sphagnum moss peat or coir dust. HortScience 38:46-54.

Solbraa, K. and A.R. Selmer-Olsen. 1981. Manganese toxicity-in particular when growing plants in bark compost. Causes, symptoms, extraction methods and precautions. Acta Agriculturae Scandinavica 31:29-39.

Tisdale, S.I., W.L. Nelson, and J.D. Beaton. 1985. Soil fertility and fertilizers. Macmillan, New York.

Tyler, H.H., W.L. Stuart, and T.E. Bilderback. 1996. Reduced leaching fractions improve irrigation use efficiency and nutrient efficacy. J. Environ. Hort. 14:199-204.

Weston, L.A. and B.H. Zandstra. 1989. Transplant age and $\mathrm{N}$ and $\mathrm{P}$ nutrition effects on growth and yield of tomatoes. HortScience 24:88-90.

Williams, K.A. and P.V. Nelson. 1996. Modifying a soilless root medium with aluminum influences phosphorus retention and chrysanthemum growth. HortScience 31:381-384.

Wittwer, S.R. 1969. Regulation of phosphorus nutrition of horticultural crops. HortScience 4:320-322.

Yeager, T.H. and R.D. Wright. 1981. Influence of nitrogen and phosphorus on shoot:root ratio of Ilex crenata Thunb. cv. Helleri. HortScience 16:564-565.

Yeager, T.H. and R.D. Wright. 1982. Phosphorus requirement of Ilex crenata Thunb. cv. Helleri grown in a pine bark medium. J. Amer. Soc. Hort. Sci. 107:558-562.

Zhang, Y.J., L. Kuhns, J.P. Lynch, and K.M. Brown. 2002. Buffered phosphorus fertilizer improves growth and drought tolerance of woody landscape plants. J. Environ. Hort. 20:214-219. 